\title{
Effect of Injector Opening Pressure and Injection Timing on Exhaust Emissions and Combustion Characteristics of Rice Bran Oil in Crude Form and Biodiesel Form in Direct Injection Diesel Engine
}

\author{
N. Durga Prasada Rao ${ }^{1}$, M.V.S.Murali Krishna ${ }^{2}$, B. Anjeneya Prasad ${ }^{3}$ \\ and P.V. K. Murthy ${ }^{4}$ \\ ${ }^{I}$ Production Department, Hindustan Aeronautics Limited, Bangalore- 560017 \\ ${ }^{2}$ Mechanical Engineering Department, Chaitanya Bharathi Institute of Technology, \\ Gandipet, Hyderabad-500 075, Andhra Pradesh, India \\ ${ }_{3}^{3}$ Mechanical Engineering Department, J.N.T. U. College of Engineering, Hyderabad- 500 085, \\ ${ }^{4}$ Jaya Prakash Narayan Educational Society Group of Institutions, Mahabubnagar-509001, Andhra Pradesh, \\ India.
}

\begin{abstract}
Investigations were carried out to determine exhaust emissions and combustion characteristics of a conventional diesel engine with different operating conditions [normal temperature and pre-heated temperature] of rice bran oil in crude form and in biodiesel form with varied injection timing and injector opening pressure. Exhaust emissions [smoke and oxides of nitrogen] and combustion characteristics [peak pressure, time of occurrence of peak pressure and maximum rate of pressure] were determined at full load operation of the engine fuelled with diesel, crude rice bran oil and rice bran oil based biodiesel. Comparative studies on exhaust emissions and combustion characteristics were made among diesel, crude vegetable oil and biodiesel operation on diesel engine with varied engine parameters. Smoke levels decreased and NOx levels increased with biodiesel operation. Exhaust emissions and combustion characteristics improved with increase of injector opening pressure, advanced injection timing and preheating of vegetable oil(s).
\end{abstract}

Keywords: - Need for Alternate Fuels, Vegetable Oil, Biodiesel, LHR combustion chamber, Performance.

\section{INTRODUCTION}

This section deals with need and necessity of alternative fuels and various alternative fuels. Investigations carried out by various researchers on crude vegetable oils and biodiesel at normal temperature and preheated temperature in compression ignition engine were mentioned. Effect of increase of injector opening pressure and injection timing on exhaust emissions was given with vegetable oils and biodiesel. Conclusions from their investigations were given. Objectives of the investigations were given at the end of the section

The rapid depletion of petroleum fuels and their ever increasing costs have lead to an intensive search for alternate fuels.

It has been found that the vegetable oils are promising substitute, because of their properties are similar to those of diesel fuel and they are renewable and can be easily produced. Rudolph Diesel, the inventor of the diesel engine that bears his name, experimented [1] with fuels ranging from powdered coal to peanut oil. Several researchers [2-6] experimented the use of vegetable oils as fuel on diesel engine and reported that the performance was poor, citing the problems of high viscosity, low volatility and their polyunsaturated character.

Experiments were conducted [7-10] on preheated vegetable oils [temperature at which viscosity of the vegetable oils were matched to that of diesel fuel]. It was reported that preheated vegetable oils decreased pollution levels of smoke and NOx emissions. The problems of crude vegetable oils can be solved, if these oils are chemically modified to bio-diesel [11].

Bio-diesels derived from vegetable oils present a very promising alternative to diesel fuel since biodiesels have numerous advantages compared to fossil fuels as they are renewable, biodegradable, provide energy security and foreign exchange savings besides addressing environmental concerns and socio-economic issues. Experiments were carried out [11-16] with bio-diesel on direct injection diesel engine. It was reported from their investigations that biodiesel operation decreased smoke emissions and increased NOx emissions in comparison with pure diesel operation.

By controlling the injector opening pressure and the injection rate, the spray cone angle is found [17] to depend on injector opening pressure. Few investigators [18-20] reported that injector opening pressure has a 
significance effect on the performance and formation of pollutants inside the direct injection diesel engine combustion. Venkanna et al.[20] used honne/diesel blend in DI diesel engine with increased injector opening pressure and increased injection rate. It was reported that smoke emissions decreased with increase of injector opening pressure.

The other important engine variable to improve the performance of the engine is injection timing. Performance improved or deteriorated depending on whether injection timing was advanced (injection timing away from TDC) or retarded (injection timing towards TDC). Recommended injection timing was defined by the manufacturer that it is the timing at which maximum thermal efficiency was obtained with minimum pollution levels from the engine.

Investigations were carried out [21-24] on single cylinder water cooled vertical diesel engine with brake power $3.68 \mathrm{~kW}$ at a speed of $1500 \mathrm{rpm}$ with varied injection timing from $27-34^{\circ} \mathrm{bTDC}$ and it was reported that performance of the engine improved with advanced injection timing, increased NOx emissions and decreased smoke levels.

Little literature was available on comparative studies on exhaust emissions and combustion characteristics with rice bran oil in crude form and biodiesel form with diesel engine. Hence it was attempted here to determine exhaust emissions and combustion characteristics with rice bran oil in crude form and biodiesel at different operating conditions with varied injection timing and injector opening pressure.

\section{MATERIALS AND METHODS}

This part deals with preparation of biodiesel, properties of biodiesel, crude vegetable oil along with diesel fuels, brief description of experimental set-up, specification of experimental engine, operating conditions and definitions of used values.

Due to very high free fatty acid, rice bran oil was converted into methyl ester by the two stage process [25]. In the first stage rice bran oil was reacted with $\mathrm{CH} 3 \mathrm{OH}$ in presence of an acid catalyst (H2SO4) to convert free fatty acid into fatty ester. A specified amount $1000 \mathrm{~g}$ of rice bran oil was taken in a round bottom flask and heated up to $60-65^{\circ} \mathrm{C}$. In a separate flasks $\mathrm{CH} 3 \mathrm{OH}(950 \mathrm{~g})$ and $\mathrm{H} 2 \mathrm{SO} 4(22 \mathrm{~g})$ were taken and properly mixed and then stirred for $4 \mathrm{~h}$ and maintained at $60^{\circ} \mathrm{C}$.It was allowed to cool overnight without stirring. When acid number of the mixture reaches to less than 1, the second stage was started. During this stage, a mixture $1000 \mathrm{~g}$ obtained from the first stage was taken in around bottom flask and heated up to $60^{\circ} \mathrm{C}$. Methanol $(200 \mathrm{ml})$ and $\mathrm{KOH} 4.5 \mathrm{~g}$ were properly mixed in other flask and then introduced into the round bottom flask containing the mixture from first stage. The mixture stirred vigorously for $2 \mathrm{~h}$ and then allowed to cool overnight. Glycerol was separated by adding warm water at $60^{\circ} \mathrm{C}$ to the mixture. Glycerol and soap formed during the process settled down the bottom. Top layer containing rice bran oil methyl ester $91 \%$ was removed with the help of a separating funnel and wasted two times with water and dried.

The physic-chemical properties of the crude vegetable oil and biodiesel in comparison to ASTM biodiesel standards are presented in Table-1.

Table.1. Properties of Test Fuels

\begin{tabular}{|c|c|c|c|c|c|}
\hline Property & Units & Diesel & $\begin{array}{c}\text { Crude } \\
\text { Vegetable oil } \\
\text { (CRBO) }\end{array}$ & $\begin{array}{c}\text { Biodiesel } \\
\text { (ERBO) }\end{array}$ & $\begin{array}{l}\text { ASTM D 6751- } \\
02\end{array}$ \\
\hline Carbon chain & -- & $\mathrm{C}_{8}-\mathrm{C}_{28}$ & $\mathrm{C}_{12}-\mathrm{C}_{20}$ & $\mathrm{C}_{16}-\mathrm{C}_{24}$ & $\mathrm{C}_{12}-\mathrm{C}_{22}$ \\
\hline Cetane Number & & 55 & 45 & 52 & $48-70$ \\
\hline Density & $\mathrm{gm} / \mathrm{cc}$ & 0.84 & 0.90 & 0.86 & $0.87-0.89$ \\
\hline $\begin{array}{l}\text { Bulk modulus @ } \\
\text { 20Mpa }\end{array}$ & Мpa & 1475 & 2050 & 1800 & NA \\
\hline $\begin{array}{l}\text { Kinematic } \\
\text { viscosity @ 40 } \mathrm{C}\end{array}$ & $\mathrm{cSt}$ & 2.25 & 4.5 & 3.5 & $1.9-6.0$ \\
\hline Sulfur & $\%$ & 0.25 & 0.4 & 0.0 & 0.05 \\
\hline Oxygen & $\%$ & 0.3 & 0.2 & 11 & 11 \\
\hline $\begin{array}{l}\text { Air fuel ratio } \\
\text { ( stochiometric) }\end{array}$ & -- & 14.86 & 15.5 & 13.8 & 13.8 \\
\hline $\begin{array}{l}\text { Lower calorific } \\
\text { value }\end{array}$ & $\mathrm{kJ} / \mathrm{kg}$ & 42000 & 39000 & 38500 & 37518 \\
\hline $\begin{array}{l}\text { Flash point } \\
\text { (Open cup) }\end{array}$ & ${ }^{\circ} \mathrm{C}$ & 66 & 190 & 174 & 130 \\
\hline Molecular weight & & 226 & 290 & 261 & 292 \\
\hline $\begin{array}{l}\text { Preheated } \\
\text { temperature }\end{array}$ & ${ }^{\circ} \mathrm{C}$ & -- & 85 & 65 & -- \\
\hline Colour & & Light yellow & Dark yellow & $\begin{array}{l}\text { Yellowish } \\
\text { orange }\end{array}$ & --- \\
\hline
\end{tabular}


Schematic diagram of experimental setup used for the investigations on compression ignition diesel engine with crude vegetable oil (CRBO) and biodiesel (ERBO) is shown in Fig. 1.

The test fuels used in the experimentation were pure diesel, rice bran oil based biodiesel and crude rice bran oil. The schematic diagram of the experimental setup with test fuels is shown in Fig. 1. The specifications of the experimental engine are shown in Table-2. The combustion chamber consisted of a direct injection type with no special arrangement for swirling motion of air. The engine was connected to an electric dynamometer for measuring its brake power. Burette method was used for finding fuel consumption of the engine. Airconsumption of the engine was measured by an air-box method (Air box was provided with an orifice flow meter and U-tube water manometer). The naturally aspirated engine was provided with water-cooling system in which inlet temperature of water was maintained at $80^{\circ} \mathrm{C}$ by adjusting the water flow rate. Engine oil was provided with a pressure feed system. No temperature control was incorporated, for measuring the lube oil temperature. Copper shims of suitable size were provided in between the pump body and the engine frame, to vary the injection timing and its effect on the performance of the engine was studied, along with the change of injector opening pressure from 190 bar to 270 bar (in steps of 40 bar) using nozzle testing device. The maximum injector opening pressure was restricted to 270 bar due to practical difficulties involved. Exhaust gas temperature was measured with thermocouples made of iron and iron-constantan.

Table.2. Specifications of the Test Engine

\begin{tabular}{|l|l|}
\hline \multicolumn{1}{|c|}{ Description } & \multicolumn{1}{c|}{ Specification } \\
\hline Engine make and model & Kirloskar ( India) AV1 \\
\hline $\begin{array}{l}\text { Maximum power output at a speed of } \\
1500 \mathrm{rpm}\end{array}$ & $3.68 \mathrm{~kW}$ \\
\hline $\begin{array}{l}\text { Number of cylinders } \times \text { cylinder position } \times \\
\text { stroke }\end{array}$ & One $\times$ Vertical position $\times$ four-stroke \\
\hline Bore $\times$ stroke & $80 \mathrm{~mm} \times 110 \mathrm{~mm}$ \\
\hline Method of cooling & Water cooled \\
\hline Rated speed $($ constant) & $1500 \mathrm{rpm}$ \\
\hline Fuel injection system & In-line and direct injection \\
\hline Compression ratio & $16: 1$ \\
\hline BMEP @ 1500 rpm & 5.31 bar \\
\hline $\begin{array}{l}\text { Manufacturer's recommended injection } \\
\text { timing and pressure }\end{array}$ & $27^{\circ}$ bTDC $\times 190$ bar \\
\hline Dynamometer & Electrical dynamometer \\
\hline Number of holes of injector and size & Three $\times 0.25 \mathrm{~mm}$ \\
\hline Type of combustion chamber & Direct injection type \\
\hline Fuel injection nozzle & $\begin{array}{l}\text { Make: } \text { MICO-BOSCH } \\
\text { No- } 0431-202-120 / \mathrm{HB}\end{array}$ \\
\hline Fuel injection pump & Make: BOSCH: NO- $8085587 / 1$ \\
\hline
\end{tabular}

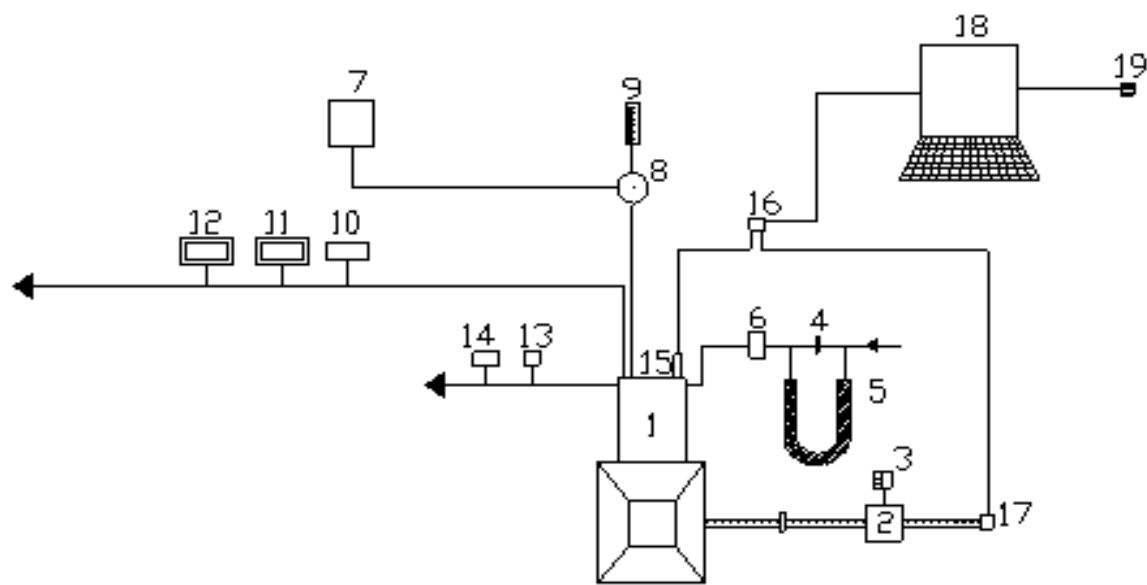

1.Engine, 2.Electical Dynamometer, 3.Load Box, 4.Orifice flow meter, 5.U-tube water manometer, 6.Air box, 7.Fuel tank, 8, Pre-heater, 9.Burette, 10. Exhaust gas temperature indicator, 11.AVL Smoke meter, 12.Netel Chromatograph NOx Analyzer, 13.Outlet jacket water temperature indicator, 14. Outlet-jacket water flow meter, 15.Piezo-electric pressure transducer, 16.Console, 17.TDC encoder, 18.Pentium Personal Computer and 19. Printer. 
Fig.1 Experimental Set-up

Exhaust emissions of smoke and $\mathrm{NO}_{\mathrm{x}}$ were recorded by AVL (A company trade name) smoke meter and Netel Chromatograph (A company trade name) NOx analyzer respectively at full load operation of the engine. The specifications of the analyzers were given in Table-3.

Table 3. Specifications of Analyzers

\begin{tabular}{|l|l|l|l|}
\hline Name of the analyzer & Measuring Range & Precision & Resolution \\
\hline AVL Smoke meter & $0-100 \mathrm{HSU}$ & $1 \mathrm{HSU}$ & $1 \mathrm{HSU}$ \\
\hline $\begin{array}{l}\text { Netel Chromatograph } \\
\text { NOx analyzer }\end{array}$ & $0-2000 \mathrm{ppm}$ & $2 \mathrm{ppm}$ & $1 \mathrm{ppm}$ \\
\hline
\end{tabular}

Piezo electric transducer, fitted on the cylinder head to measure pressure in the combustion chamber was connected to a console, which in turn was connected to Pentium personal computer. TDC (top dead centre) encoder provided at the extended shaft of the dynamometer was connected to the console to measure the crank angle of the engine. A special P- $\theta$ software package evaluated the combustion characteristics such as peak pressure (PP), time of occurrence of peak pressure (TOPP), maximum rate of pressure rise (MRPR) and time of occurrence of maximum rate of pressure rise (TOMRPR) from the signals of pressure and crank angle at the full load operation of the engine. Pressure-crank angle diagram was obtained on the screen of the personal computer.

Various test fuels used in experimentation were pure diesel, crude rice bran oil and rice bran oil based biodiesel. Different operating conditions of the biodiesel and crude rice bran oil were normal temperature and preheated temperature. Different injector opening injector opening pressures attempted in this experimentation were $190 \mathrm{bar}, 230 \mathrm{bar}$ and $270 \mathrm{bar}$. Various injection timings attempted in the investigations were $27-34^{\circ} \mathrm{bTDC}$.

Recommended injection timing: It is the injection timing of the engine with maximum efficiency of the engine with minimum pollution levels.

Optimum injection timing: It is injection timing at which maximum thermal efficiency was obtained at all loads and beyond this injection timing, efficiency of the engine decreased.

\section{RESULTS AND DISCUSSION}

Results and discussion were made in two parts such as 1. Determination of optimum injection timing with crude rice bran oil and biodiesel, 2. Determining exhaust emissions and 3. Determining the combustion characteristics. Data of pure diesel was taken from reference [11].

\subsection{Performance}

Fig. 2 indicates that BTE increased up to 80\% of BMEP (BMEP at full load=5.3 bar) and beyond that load it decreased with test fuels. This was due to increase of fuel conversion efficiency up to $80 \%$ of the full load and decrease of air fuel ratios [11] and reduction of volumetric efficiency beyond $80 \%$ of the full load causing reduction in thermal efficiency. Although carbon accumulations on the nozzle tip might play a partial role for the general trends observed, the difference of viscosity between the diesel and crude vegetable oil provided a possible explanation for the deterioration in the performance of the engine with crude vegetable oil operation. Furthermore droplet mean diameters (expressed as Sauter mean) were larger [11] for crude vegetable oil leading to reduce the rate of heat release [26] as compared with diesel fuel. This also, contributed the higher ignition (chemical) delay of the crude vegetable oil due to lower cetane number. BTE increased with the advancing of the injection timing in engine with the crude vegetable oil at all loads, when compared with engine at the recommended injection timing and pressure.

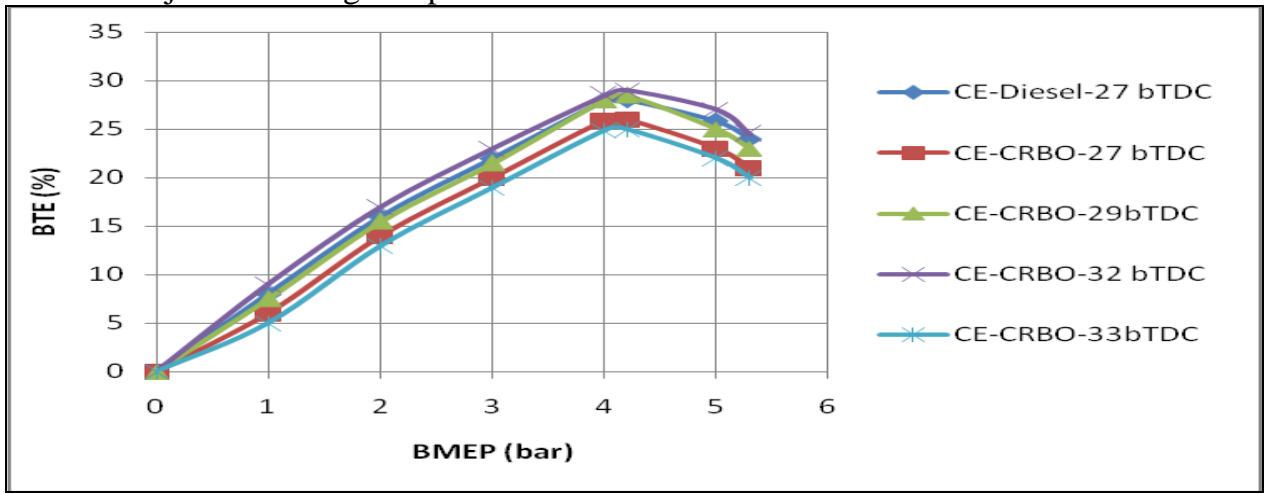

Fig. 2 Variation of brake thermal efficiency (BTE) with brake mean effective pressure (BMEP) in compression ignition diesel engine (CE) at different injection timings with crude rice brawn oil (CRBO) operation. 
This was due to initiation of combustion at earlier period and efficient combustion with increase of air entrainment in fuel spray giving higher BTE. BTE increased at all loads when the injection timing was advanced to $32^{\circ} \mathrm{bTDC}$ in the CE at the normal temperature of CRBO. Increase of BTE at optimum injection timing over the recommended injection timing with crude vegetable oil with compression ignition engine could be attributed to its longer ignition delay and combustion duration [26-27].

Curves of Fig. 3 indicate that compression ignition engine with biodiesel showed the compatible performance for entire load range when compared with the pure diesel operation on $\mathrm{CE}$ at $27^{\circ} \mathrm{bTDC}$. This was due to difference of viscosity between the diesel and biodiesel causing compatible performance of the engine with biodiesel operation. This was also due to lower calorific value of the biodiesel. BTE increased at all loads when the injection timing was advanced to $31^{\circ} \mathrm{bTDC}$ in the engine at the normal temperature of biodiesel. The increase of BTE at optimum injection timing over the recommended injection timing with biodiesel with CE could be attributed to its longer ignition delay and combustion duration. BTE increased at all loads when the injection timing was advanced to $31^{\circ} \mathrm{bTDC}$ in CE.

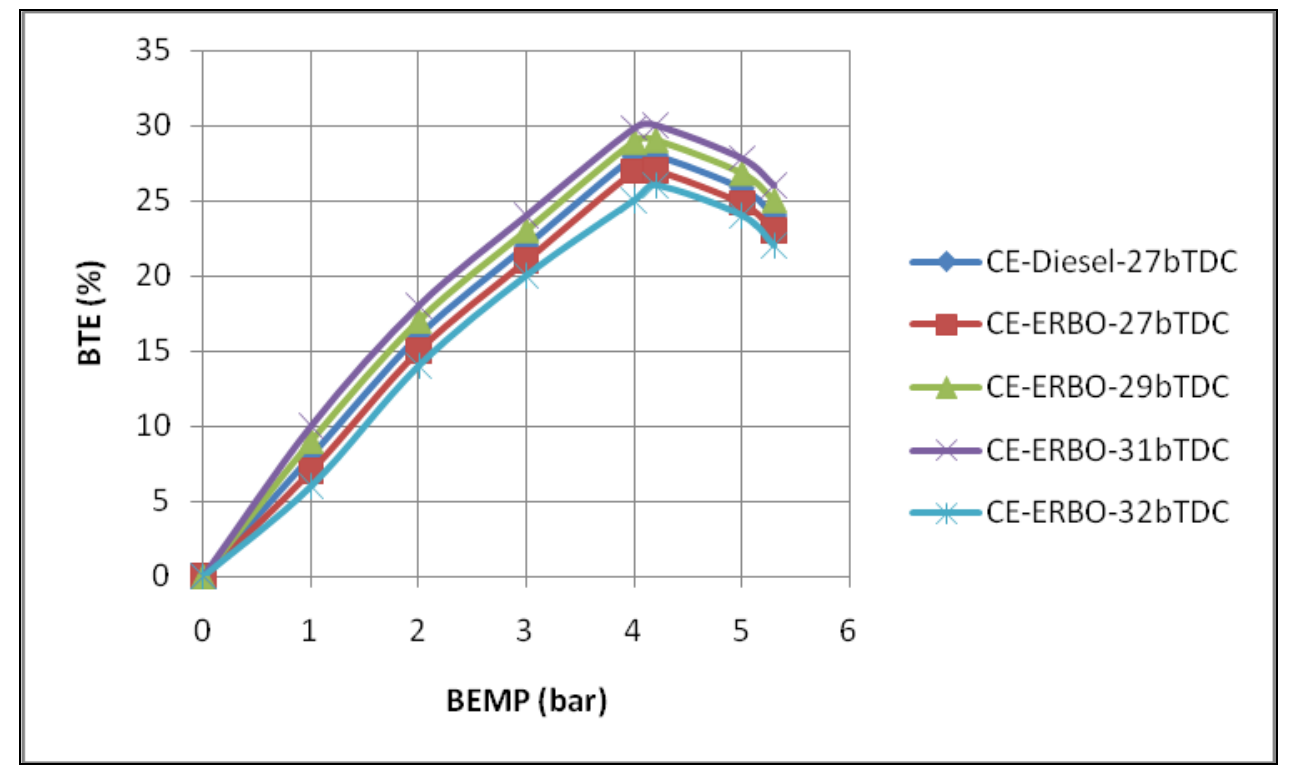

Fig. 3 Variation of brake thermal efficiency (BTE) with brake mean effective pressure (BMEP) in compression ignition diesel engine (CE) at different injection timings with biodiesel (ERBO) operation.

Part load variations were very small and minute for the performance parameters and exhaust emissions. The effect of varied injection timing (advanced injection timing) on the performance with test fuels was discussed with the help of bar charts, while the effect of increase of injector opening pressure was discussed with the help of Tables.

\subsection{Exhaust Emissions}

Smoke and NOx are the emissions from diesel engine cause [28-30] health hazards like inhaling of these pollutants cause severe headache, tuberculosis, lung cancer, nausea, respiratory problems, skin cancer, hemorrhage, etc. The contaminated air containing carbon dioxide released from automobiles reaches ocean in the form of acid rain, there by polluting water. Hence control of these emissions is an immediate task and important.

From Fig..4, it is observed that drastic increase of smoke levels at full load operation with vegetable oil (s) operation was observed compared with pure diesel operation. This was due to the higher value of ratio of $\mathrm{C} / \mathrm{H}(\mathrm{C}=$ Number of carbon atoms and $\mathrm{H}=$ Number of hydrogen atoms in fuel composition, higher the value of this ratio means, number of carbon atoms are higher leading to produce more carbon dioxide and more carbon monoxide and hence higher smoke levels) of crude vegetable oil (0.7) when compared with pure diesel (0.45). The increase of smoke levels was also due to decrease of air-fuel ratios [11] and volumetric efficiency [11] with vegetable oil (s) compared with pure diesel operation.

Smoke levels were related to the density of the fuel. Since vegetable oil (s) has higher density compared to diesel fuel, smoke levels were higher with vegetable oil(s). Smoke levels decreased [29] at the respective optimum injection timing with test fuels. This was due to initiation of combustion at early period. Smoke levels were found to be lower with biodiesel operation compared with crude vegetable oil operation at 
recommended and optimized injection timing. The inherent oxygen of biodiesel might have provided some useful interactions between air and fuel, particularly in the fuel-rich region. Certainly, it is evident proof of the oxygen content of biodiesels enhanced the oxidation of hydrocarbon reactions thus reducing smoke levels.

Smoke levels were lower with pure diesel operation followed by biodiesel and crude vegetable oil. This was due to lower value of $\mathrm{C} / \mathrm{H}$ ratio, density, air fuel ratio of the diesel fuel.

The data from Table 4 shows a decrease in smoke levels with increase of injector opening pressure, with different operating conditions of the crude vegetable oil and biodiesel. This was due to improvement in the fuel spray characteristics at higher injector opening pressure and increase of air entrainment,

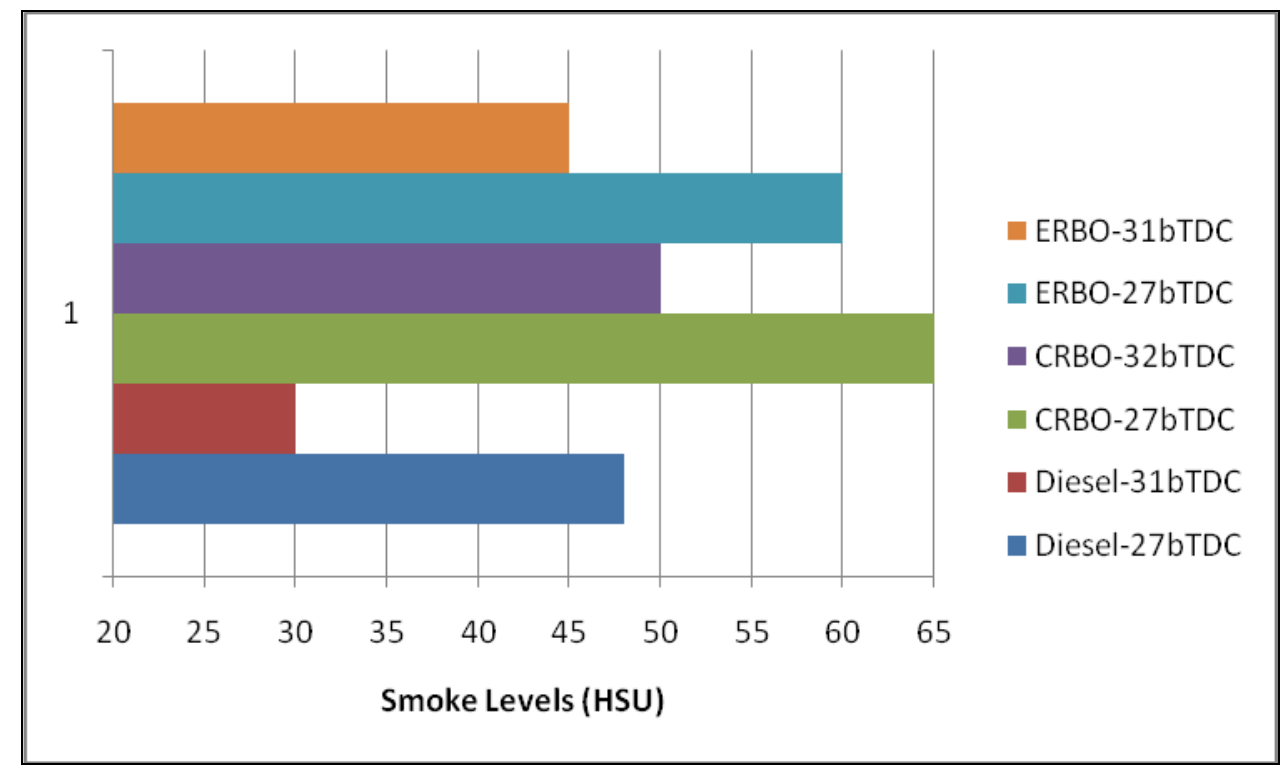

Fig. 4 Bar charts showing the variation of smoke levels in Hartridge smoke unit (HSU) at full loadoperation with test fuels at recommended and optimized injection timings at an injector opening pressure of 190 bar.

at the advanced injection timings, causing lower smoke levels. Even though viscosity of biodiesel and crude vegetable oil were higher than diesel, high injector opening pressure improves spray characteristics, hence leading to a shorter physical delay period. The improved spray also leads to better mixing of fuel and air resulting in turn in fast combustion. This will enhance the performance.

Preheating of the vegetable oil (s) reduced smoke levels, when compared with normal temperature of the vegetable oil(s). This was due to i) the reduction of density of the vegetable oil (s), as density was directly related to smoke levels, ii) the reduction of the diffusion combustion proportion with the preheated vegetable oil (s), iii) the reduction of the viscosity of the vegetable oil (s), with which the fuel spray does not impinge on the combustion chamber walls of lower temperatures rather than it directed into the combustion chamber.

Crude vegetable oil at its different operating conditions gave higher value of smoke levels in comparison with biodiesel in both versions of the engine Due to higher molecular weight, crude vegetable oil has low volatility and because of their un-saturation, crude vegetable oil is inherently more reactive than biodiesel, which results that they are more susceptible to oxidation and thermal polymerization reactions. The different fatty acids present in the vegetable oil are palmic, steric, lingoceric, oleic, linoleic and fatty acids [6]. These fatty acids increase smoke emissions and also lead to incomplete combustion due to improper air-fuel mixing. By the esterification process, the viscosity of the vegetable oil was brought down many times lower than the viscosity of the raw or crude vegetable oil. This was because of the removal of glycerol molecules, which caused the vegetable oil to be more viscous. Since there was drop in the viscosity, naturally the density of the esterified oil was also dropped at the room temperature. Volatility of the vegetable oil also increased with the esterification process. Hence biodiesel reduced smoke levels when compared to the crude vegetable oil.

Smoke levels were lower with diesel operation followed by biodiesel and crude vegetable oil. This was due to the nature of the composition of the diesel fuel. Diesel fuel has lower value of $\mathrm{C} / \mathrm{H}$, lower viscous and lower theoretical air fuel ratio. 
TABLE.4. DATA OF EXHAUST EMISSIONS AT FULL LOADOPERATION

\begin{tabular}{|c|c|c|c|c|c|c|c|c|c|c|c|c|c|}
\hline \multirow{4}{*}{$\begin{array}{l}\text { Injection } \\
\text { Timing } \\
\left({ }^{\circ} \mathrm{bTDC}\right)\end{array}$} & \multirow{4}{*}{ Test Fuel } & \multirow{2}{*}{\multicolumn{6}{|c|}{$\begin{array}{c}\text { Smoke Levels (Hartridge Smoke Unit) } \\
\text { Injector Opening Pressure (Bar) }\end{array}$}} & \multicolumn{6}{|c|}{ NOx Levels(ppm) } \\
\hline & & & & & & & & \multicolumn{6}{|c|}{ Injector Opening Pressure (Bar) } \\
\hline & & \multicolumn{2}{|c|}{190} & \multicolumn{2}{|c|}{230} & \multicolumn{2}{|c|}{270} & \multicolumn{2}{|c|}{190} & \multicolumn{2}{|c|}{230} & \multicolumn{2}{|c|}{270} \\
\hline & & NT & PT & NT & PT & NT & PT & NT & PT & $\mathrm{NT}$ & PT & NT & PT \\
\hline \multirow{3}{*}{27} & DF & 48 & -- & 38 & -- & 34 & -- & 850 & $\ldots$ & 900 & $\ldots$ & 950 & -- \\
\hline & ERBO & 60 & 55 & 55 & 50 & 50 & 45 & 950 & 900 & 1000 & 950 & 1050 & 1000 \\
\hline & CRBO & 65 & 60 & 60 & 55 & 55 & 50 & 700 & 650 & 750 & 700 & 800 & 750 \\
\hline \multirow{2}{*}{31} & DF & 30 & -- & 35 & -- & 40 & -- & 1100 & - & 1150 & - & 1200 & -- \\
\hline & ERBO & 45 & 40 & 50 & 45 & 55 & 50 & 1150 & 1100 & 1200 & 1150 & 1250 & 1200 \\
\hline 32 & CRBO & 50 & 45 & 55 & 50 & 60 & 55 & 900 & 850 & 950 & 900 & 1000 & 950 \\
\hline
\end{tabular}

DE- Diesel fuel, TSOBD- Biodiesel, CTSO- Crude vegetable oil, NT- Normal temperature , PT- Preheated temperature

Temperature and availability of oxygen are two favorable conditions to form NOx levels. At peak load, NOx levels increased with test fuels at recommended injection timing due to higher peak pressures, temperatures as larger regions of gas burned at close-to-stoichiometric ratios.

It is noticed from Fig..5, that NOx levels were lower with crude vegetable oil operation at the full load when compared with diesel operation. This was due to lower heat release rate [28] because of high duration of combustion (high viscous fuels) causing lower gas temperatures with the vegetable oil operation, which decreased NOx levels. The tobacco seed oil based biodiesel having long carbon chain $\left(\mathrm{C}_{20}-\mathrm{C}_{32}\right)$ [25] recorded

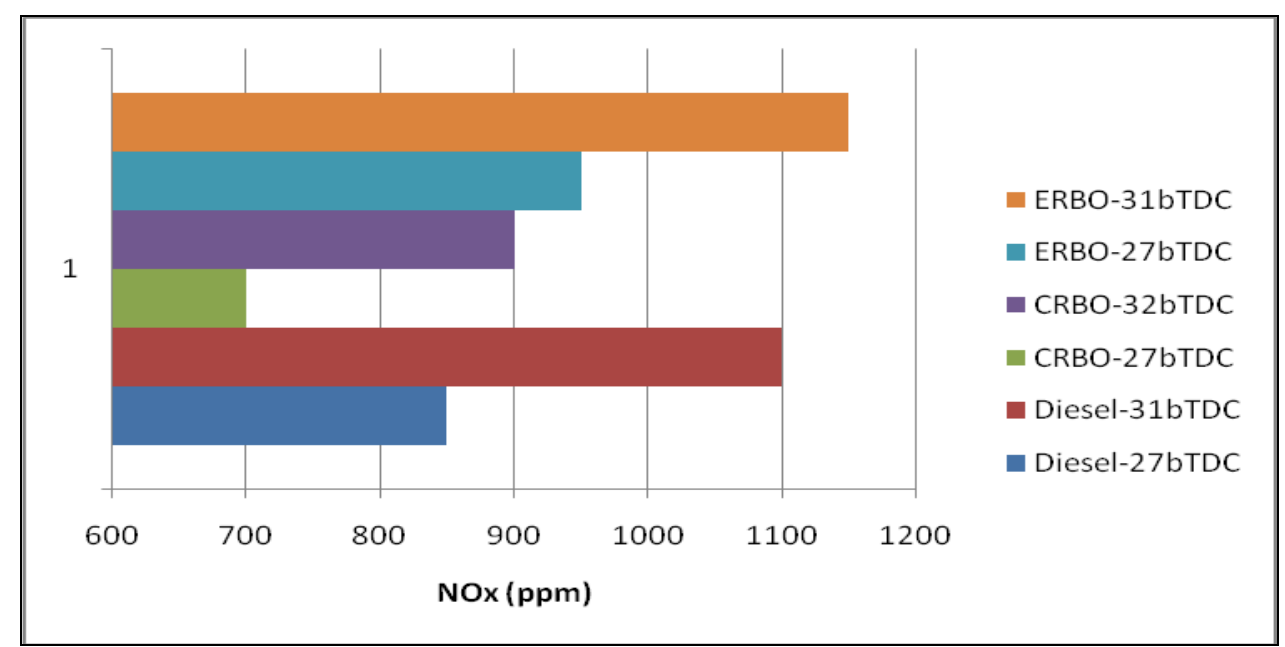

Fig. 5 Bar charts showing the variation of NOx levels at full loadoperation with test fuels at recommended and optimized injection timings at an injector opening pressure of 190 bar.

more NOx than that of fossil diesel having both medium $\left(\mathrm{C}_{8}-\mathrm{C}_{14}\right)$ as well as long chain $\left(\mathrm{C}_{16}-\mathrm{C}_{28}\right)$. The increase in NOx emission might be an inherent characteristic of biodiesel due to the presence of $54.9 \%$ of monounsaturated fatty acids(MUFA) and $18 \%$ of poly-unsaturated fatty acids (PUFA). That means, the long chain unsaturated fatty acids (MUFA and FUPA) such as oleic C18:1 and linoliec C18:2 fatty acids are mainly responsible for higher levels of NOx emission [25]. Another reason for higher NOx levels is the oxygen (10\%) present in the methyl ester. The presence of oxygen in normal biodiesel leads to improvement in oxidation of the nitrogen available during combustion. This will raise the combustion bulk temperature responsible for thermal NOxformation. Many researchers reported that oxygen [26] and nitrogen [27] content of biodiesel can cause an increase in NOx emissions. The production of higher NOx with biodiesel fueling is also attributable to an inadvertent advance of fuel injection timing due to higher bulk modulus of compressibility, with the in-line fuel injection system.

Residence time and availability of oxygen had increased, when the injection timing was advanced with test fuels, which caused higher NOx levels.

From the Table 4, it is noted that NOx levels increased with increase of injector opening pressure with different operating conditions of vegetable oil (s) as it is noticed from the Table.4.

NO $x$ slightly increased with test fuels as injector opening pressure increased. This was because of improved combustion causes higher peak brake thermal efficiency due to higher combustion chamber pressure (Table.5) and temperature and leads to higher NOx formation. This is an evident proof of enhanced spray characteristics, thus improving fuel air mixture preparation and evaporation process. 
NOx levels decreased with preheating of the vegetable oil (s) as noticed from the Table.4. The fuel spray properties may be altered due to differences in viscosity and surface tension. The spray properties affected may include droplet size, droplet momentum, degree of mixing, penetration, and evaporation. The change in any of these properties may lead to different relative duration of premixed and diffusive combustion regimes. Since the two burning processes (premixed and diffused) have different emission formation characteristics, the change in spray properties due to preheating of the vegetable oil (s) are lead to reduction in NOx formation. As fuel temperature increased, there was an improvement in the ignition quality, which will cause shortening of ignition delay. A short ignition delay period lowers the peak combustion temperature which suppresses NOx formation [26]. Lower levels of NOx is also attributed to retarded injection, improved evaporation, and well mixing of preheated vegetable oil (s) due to their viscosity at preheated temperatures. Biodiesel has higher value of NOx emissions followed by diesel and crude vegetable oil. This was because of inherent nature of biodiesel as it has oxygen molecule in its composition.

\subsection{Combustion Characteristics}

From the Fig.6, it is noticed that peak pressure for normal biodiesel was slightly higher than that of diesel fuel; even though biodiesel was having lower value of lower calorific value. Biodiesel advanced the peak pressure position as compared to fossil diesel because of its higher bulk modulus and cetane number. This shift is mainly due to advancement of injection due to higher density and earlier combustion due to shorter ignition delay caused by higher cetane number of biodiesel. When, a high density (or high bulk modulus) fuel is injected, the pressure wave travels faster from pump end to nozzle end, through a high pressure in-line tube [26]. This causes early lift of needle in the nozzle, causing advanced injection. Hence, the combustion takes place very close to TDC (lower value of time of occurrence of peak pressure) and the peak pressure slightly high due to existence of smaller cylinder volume near TDC.

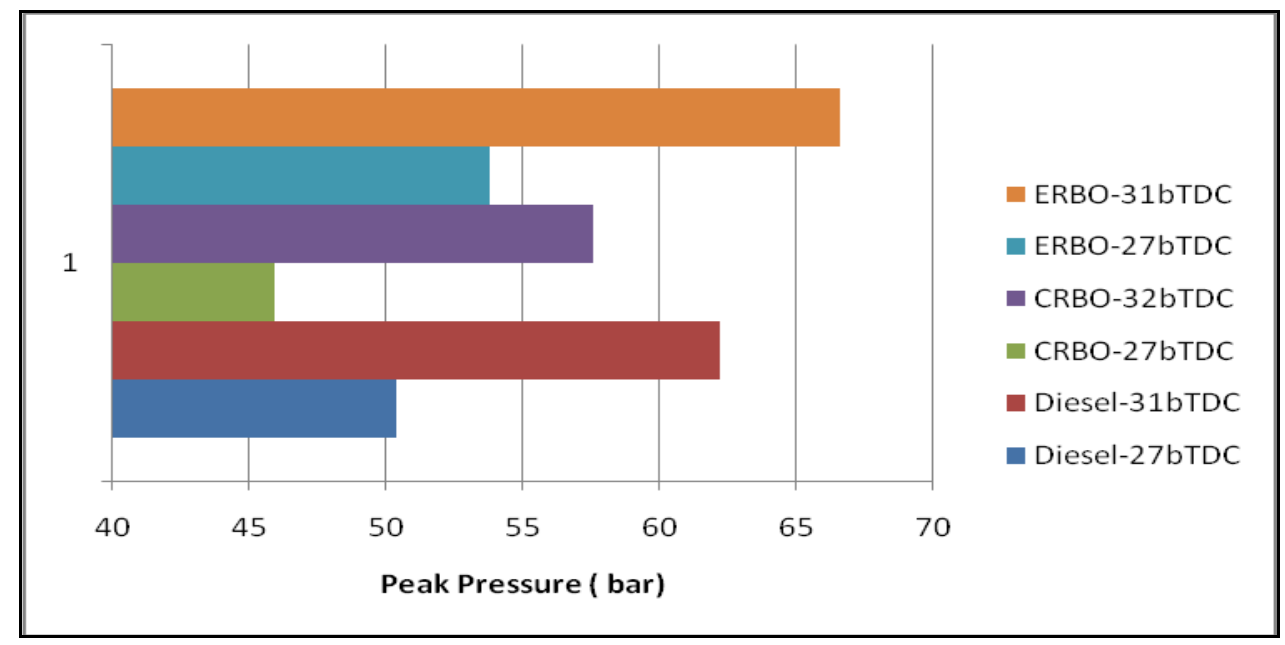

Fig. 6 Bar charts showing the variation of peak pressure at full load operation with test fuels at recommended and optimized injection timings at an injector opening pressure of $190 \mathrm{bar}$.

However, the peak pressures of preheated methyl ester were less than that of fossil diesel and biodiesel (Table.5). When the engine is running on preheated biodiesel the fuel injection was slightly delayed, due to decrease in bulk modulus of biodiesel with the increase in fuel temperature. The reasons for lower peak pressures of preheated vegetable oil (s) was also attributed to earlier combustion caused by short ignition delay (due to faster evaporation of the fuel) at their preheated temperatures.

From Table-5, it is observed that peak pressures were lower with crude vegetable oil at the recommended injection timing and pressure, when compared with pure diesel operation. This was due to increase of ignition delay, as crude vegetable oil requires high duration of combustion. Mean while the piston started making downward motion thus increasing volume when the combustion takes place. This was also due to low cetane value of crude vegetable oil.

Peak pressures increased with the increase of injector opening pressure and with the advancing of the injection timing with the test fuels. Peak pressure increased as injector opening increased. This may be due to smaller sauter mean diameter [26] shorter breakup length, better dispersion, and better spray and atomization characteristics. This improves combustion rate in the premixed combustion phase. Maximum rate of pressure rise (MRPR) was highest (Fig.7) for normal diesel followed by the biodiesel and crude vegetable oil. With 
biodiesel, as injector opening pressure increased, spray characteristic improved and in turn burned fuel increased again and in turn combustion rate increased in the premixed combustion phase [26].

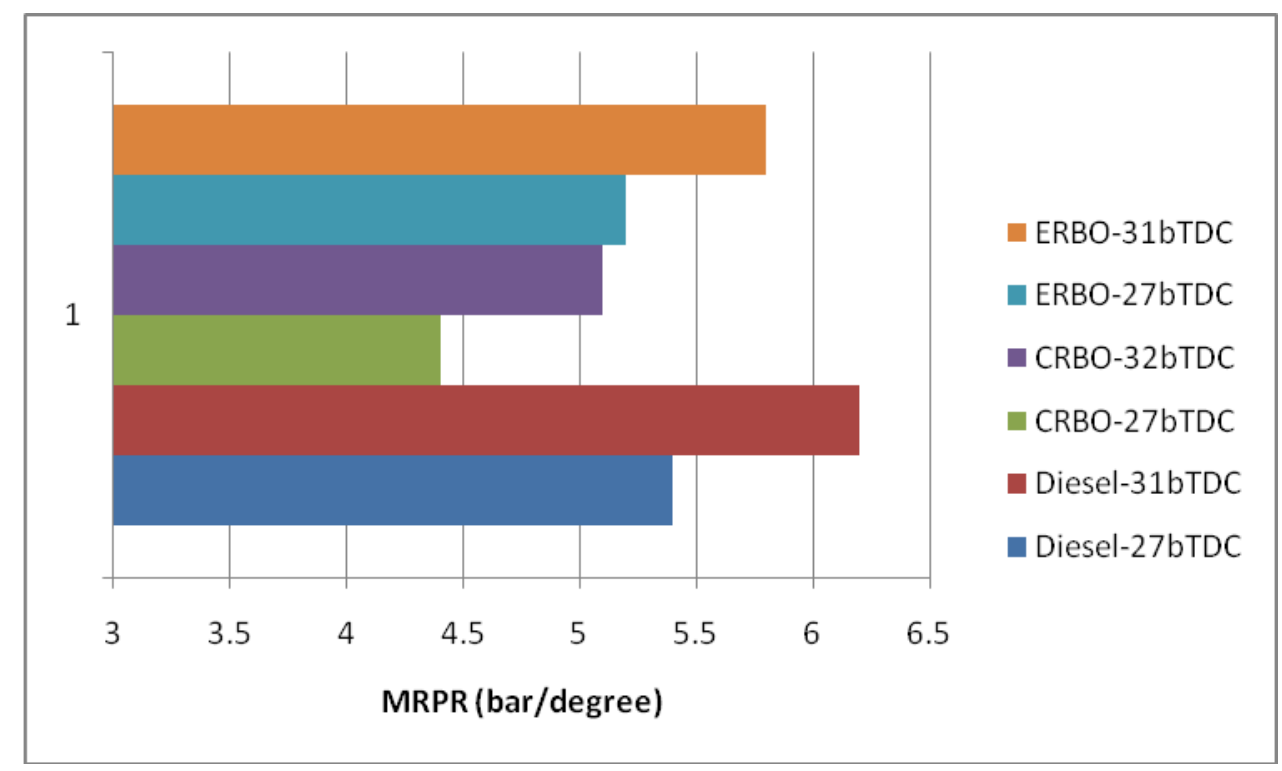

Fig.. 7. Bar charts showing the variation of maximum rate of pressure rise at full loadoperation with test fuels at recommended and optimized injection timings at an injector opening pressure of $190 \mathrm{bar}$.

When the engine is operated under the full load condition, the mechanical loading is at the maximum level. The differences [20] in maximum rate of pressure rise, the peak cylinder pressure, and the occurrence of peak cylinder pressure during the maximum mechanical loading may cause performance loses. In the present work both peak cylinder pressure and maximum rate of pressure rise of biodiesel was lower and occurrence of peak cylinder pressure slightly deviated away when compared to normal diesel [25].

The value of time of occurrence of peak pressure (TOPP) decreased with the advancing of the injection timing and with increase of injector opening pressure at different operating conditions of the test fuels. TOPP was found to be marginally higher with crude vegetable oil when compared with biodiesel operation.

This once again established the fact by observing lower peak pressures and higher TOPP, that crude vegetable oil operation showed deterioration in the performance and compatible performance with biodiesel operation when compared with pure diesel operation.

Preheating of the vegetable oil (s) showed lower TOPP, compared with vegetable oil (s) at normal temperature. This once again confirmed by observing the lower TOPP, the performance of the engine improved with the preheated vegetable oils in crude and biodiesel form compared with the normal test fuels.

TABLE.5 DATA OF COMBUSTION CHARACTERISTICS AT FULL LOADOPERATION

\begin{tabular}{|c|c|c|c|c|c|c|c|c|c|c|c|c|c|}
\hline \multirow{4}{*}{$\begin{array}{l}\text { Injection } \\
\text { Timing } \\
\left({ }^{\circ} \mathrm{bTDC}\right)\end{array}$} & \multirow{4}{*}{ Test Fuel } & \multicolumn{4}{|c|}{ PP (bar) } & \multicolumn{4}{|c|}{ MRPR (bar/deg) } & \multicolumn{4}{|c|}{ TOPP (deg) } \\
\hline & & \multicolumn{4}{|c|}{ Injector opening pressure } & \multicolumn{4}{|c|}{ Injector opening pressure } & \multicolumn{4}{|c|}{$\begin{array}{c}\text { Injector opening } \\
\text { pressure }\end{array}$} \\
\hline & & \multicolumn{2}{|c|}{190} & \multicolumn{2}{|c|}{270} & \multicolumn{2}{|c|}{190} & \multicolumn{2}{|c|}{270} & \multicolumn{2}{|c|}{190} & \multicolumn{2}{|c|}{270} \\
\hline & & NT & PT & NT & PT & & & & & & & & \\
\hline \multirow{3}{*}{27} & DF & 50.4 & -- & 53.5 & $\cdots$ & 5.4 & -- & 6.0 & -- & 10 & & 9 & \\
\hline & TSOBD & 53.8 & 49.4 & 55.6 & 51.6 & 5.2 & 4.2 & 5.6 & 4.8 & 11 & 10 & 10 & 9 \\
\hline & CTSO & 45.9 & 43.5 & 48.2 & 46.6 & 4.4 & 3.6 & 4.9 & 3.9 & 11 & 10 & 10 & 9 \\
\hline \multirow{2}{*}{31} & $\mathrm{DF}$ & 62.2 & -- & 61.9 & -- & 6.2 & -- & 6.8 . & - & 8 & & 8 & \\
\hline & TSOBD & 66.6 & 64.1 & 68.5 & 65.5 & 5.8 & 4.8 & 6.0 & 5.2 & 8 & 8 & 8 & 8 \\
\hline 32 & CTSO & 57.6 & 54.5 & 60.5 & 57.4 & 5.1 & 4.3 & 5.4 & 4.7 & 9 & 9 & 9 & 9 \\
\hline
\end{tabular}

This trend of increase of maximum rate of pressure rise indicated improved and faster energy substitution and utilization by crude vegetable oil and biodiesel in engine, which could replace $100 \%$ diesel fuel. That too, all these combustion characters were within the limits hence the crude vegetable oil and biodiesel can be effectively substituted for diesel fuel. 


\section{CONCLUSIONS}

At recommended injection timing and pressure, when compared with pure diesel operation,

1. Smoke levels with crude vegetable oil at full load increased by $35 \%$, while biodiesel operation increased smoke levels by $25 \%$.

2. NOx levels with crude vegetable oil operation decreased by $18 \%$, while biodiesel operation increased by $11 \%$.

3. Peak pressures with crude vegetable oil at full load operation decreased by $10 \%$, while biodiesel operation increased by $6 \%$.

4. MRPR at full load with crude vegetable oil operation decreased by $19 \%$, while biodiesel operation decreased by $12 \%$.

At the respective optimized injection timing and an injector opening pressure of $190 \mathrm{bar}$, when compared with pure diesel operation,

1. Smoke levels at full loadoperation with crude vegetable oil operation increased by $67 \%$, while biodiesel operation increased by $50 \%$.

2. NOx levels at full loadoperation with crude vegetable oil operation decreased by $18 \%$, while biodiesel operation increased by $5 \%$.

3. Peak pressures with crude vegetable oil at full load operation decreased by $8 \%$, while biodiesel operation increased by $6 \%$.

4. MRPR at full load with crude vegetable oil operation decreased by $20 \%$, while biodiesel operation increased it by $12 \%$.

With increase of injector opening pressure,

Smoke levels decreased and NOx levels increased with test fuels.

With preheating

Decrease of smoke levels and NOx levels were observed with test fuels.

All the combustion parameters were within the limits and hence crude vegetable oil and biodiesel can be substituted for $100 \%$ of diesel fuel.

4.1 Research Findings and Suggestions

Comparative studies were made on combustion parameters and exhaust emissions with different operating conditions of crude vegetable oil and biodiesel with varied injection timing and injector opening pressure in direct injection diesel engine.

Vegetable oil (s) requires hot combustion chamber as they are highly viscous, and non-volatile. Hence a low heat rejection diesel engine can be employed in order to burn them effectively, with its significance characteristics of higher operating temperature, maximum heat release, and ability to handle lower calorific value (CV) fuel etc. Hence further work in this direction is necessary.

\section{ACKNOWLEDGMENTS}

Authors thank authorities of Chaitanya Bharathi Institute of Technology, Hyderabad for providing facilities for carrying out this research work. Financial assistance provided by All India Council for Technical Education (AICTE), New Delhi, was greatly acknowledged.

\section{REFERENCES}

[1] Matthias Lamping, Thomas Körfer, Thorsten Schnorbus, Stefan Pischinger, Yunji Chen : Tomorrows Diesel Fuel Diversity - Challenges and Solutions, SAE 2008-01-1731.

[2] A.K.Agarwal, Bio-fuels (alcohols and biodiesel) applications as fuels for internal combustion engines. International Journal Energy Combustion Science, 33, 2006, 233-271

[3] T.Murayama, Y. Fujiwara and T.Noto, Evaluating waste vegetable oils as a diesel fuel. Proceedings of Inst. of Mech. Engineers, Part-D, J. Automobile Eng. 214(2), 2000, 141-148.

[4] A.K.Babu, and G.Devarajane,., Vegetable oils and their derivatives as fuels for CI engines: an overview.SAE Paper No.2003-01-0767, 2003.

[5] P.K.Devan, and N.V.Mahalakshmi, Performance, emission and combustion characteristics of poon oil and its blends in a DI diesel engine. Fuel, 88, 2009, 861-870.

[6] R.D.Misra, M.S.Murthy, Straight vegetable oils usage in a compression ignition engine-A review. Renewable and Sustainable Energy Reviews, 14, 2010, 3005-3013.

[7] S.Bari, T.H.Lim, C.W.Yu, Effect of preheating of crude palm oil on injection system, performance and emission of a diesel engine. Renewable Energy, 27(3), 2002, 339-351.

[8] O.M.L.Nwafor, The effect of elevated fuel inlet temperature on the performance of diesel engine running on a neat vegetable oil at constant speed conditions. Renewable energy, 28, 2003, 171-180.

[9] M.Senthil Kumar, A.Kerihuel, J.Bellettre, and M.Tazerout, Experimental investigations on the use of preheated animal fat as fuel in a compression ignition engine. Renewable Energy, 30, 2005, 2314-2323. 
[10] D.Agarwal, A.K.Agarwal, Performance and emissions characteristics of jatropha oil (preheated and blends) in a direct injection compression ignition engine. Int. J. Applied Thermal Engineering, 27, 2007, 2314-23.

[11] R.J.Last, M.Krüger, and M.Dürnholz, Emissions and performance characteristics of a 4-stroke, direct injected diesel engine fueled with blends of biodiesel and low sulfur diesel fuel, SAE Technical Paper No. 95005,. Warrendale, PA: 400 Commonwealth Drive, 1995.

[12] Jiwak Suryawanshi,, Performance and emission characteristics of CI engine fueled by coconut oil methyl ester, SAE Paper No. 2006-32-0077, 2006.

[13] Marek Tatur, Harsha Nanjundaswamy, Dean Tomazic, Matthew Thornton., Effects of Biodiesel Operation on LightDuty Tier 2 Engine and Emission Control Systems, SAE 2008-01-0080, 2008.

[14] A.Murugesan, C.Umarani, R.Subramanian,, N.Nedunchezhian, Bio-diesel as an alternate fuel for diesel engines. Renewable and Sustainable Energy Reviews, 13(3), 2009, 653-662.

[15] Venkatramn. and G.Devaradjane, Experimental investigation of performance and emission characteristics of dieselpungam oil, methyl esters diesel blends fueled DI engine at optimum engine operating parameters, International Journal of Green energy and env, 1, 2010, 7-12.

[16] J.B.Heywood, Fundamentals of Internal Combustion Engines, (Tata McGraw Hills, New York, 1988)

[17] I.Celikten,An experimental investigation of the effect of the injection pressure on the engine performance and exhaust emission in indirect injection diesel engines, Applied Thermal engineering, 23, 2003, 2051-2060.

[18] Y.Cingur, \& D..Altiparmak, Effect of cetane number and injection pressure on a DI diesel engine performance and emissions. Energy Conversion and Management, 44, 2003, 389-397.

[19] D.T.Hountalas, D.A.Kouremenos, K.B.Binder, V.Schwarz, V., \& G.C.Mavropoulos, Effect of injection pressure on the performance and exhaust emissions of a heavy duty DI diesel engine, SAE Technical Paper No. 2003-010340. Warrendale, PA, 2003.

[20] B.K.Venkanna, \&R.C. Venkataramana, Influence of fuel injection rate on the performance, emission and combustion characteristics of DI diesel engine running on calophyllum inophyllum linn oil (honne oil)/diesel fuel blend, SAE Technical Paper No. 2010-01-1961, 2010.

[21] Chandrakasan Solaimuthu and Palani Swamy Govindaraju, Effect of injection timing on performance, combustion and emission characteristics of diesel engine using mahua oil methyl ester. Journal of Scientific and Industrial Research, 71, 2012, 69-74.

[22] N.Venkateswara Rao, M.V.S.Murali Krishna, and P.V.K.Murthy, Effect of injector opening pressure and injection timing on performance parameters of high grade low heat rejection diesel engine with tobacco seed oil based biodiesel. International Journal of Current Engineering \& Technology, 3(4), 2013, 1401-1411.

[23] N.Venkateswara Rao, M.V.S. Murali Krishna and P.V.K.Murthy, Effect of injector opening pressure and injection timing on exhaust emissions and combustion characteristics of high grade low heat rejection diesel engine with tobacco seed oil based biodiesel. International Journal of Recent Technology and Engineering, 2(4), 2013, 70-79.

[24] Venkateswara Rao, N., Murali Krishna, M.V.S. and Murthy, P.V.K., Comparative studies on exhaust emissions and combustion characteristics of tobacco seed oil in crude form and biodiesel form in direct injection diesel engine. International Journal of Mechanical and Production Engineering Research and Development, 3(4), 2013, 125-138.

[25] Subhan Kumar Mohanty., A Production of biodiesel from rice bran oil and experimenting on small capacity diesel engine, International Journal of Modern Engineering Research, 3(2), 2013, 920-923.

[26] P.V.Rao, Effect of properties of Karanja methyl ester on combustion and NOx emissions of a diesel engine, Journal of Petroleum Technology and Alternative Fuels, 2(5), 2011, 63-75.

[27] L.N.Gattamaneni, S.Saravanan, S. Santhanam, and R.Kuderu, Combustion and emission characteristics of diesel engine fuelled with rice bran oil methyl ester and its diesel blends. Thermal Science, 12, 2008, 139-150.

[28] M.H.Fulekar, Chemical pollution - a threat to human life, Indian Journal of Environmental Technology, 1, 1999, 353-359.

[29] S.M.Kapooor, Environmental Pollution Analysis, [New Age International (P) Ltd, Publishers, New Delhi], 2004, 180-190.

[30] B.K.Sharma, Engineering Chemistry, [Pragathi Prakashan (P) Ltd, Meerut], 2005, 150-160. 